\title{
THE ROLE OF THE STRUCTURE-CONDUCT-PERFORMANCE PARADIGM FOR THE DEVELOPMENT OF INDUSTRIAL ORGANIZATION ECONOMICS AND STRATEGIC MANAGEMENT
}

Zbigniew Matyjas

Department of Business Management, Faculty of Management, University of Lodz, Poland, e-mail: zmatyjas@uni.lodz.pl

\begin{abstract}
Purpose: The main purpose of the paper is to introduce the basic assumptions of the StructureConduct-Performance paradigm, its origin and subsequent significant changes, methods of empirical confirmation of its existence and its importance for the development of Industrial Organization Economics and Strategic Management.
\end{abstract}

Approach: The basic methodological approach to this article is descriptive one, based largely on a review of the literature on Structure-Conduct-Performance Paradigm topic and drawing final conclusions.

Implications for society: The development of both Industrial Organization Economics, as well as Strategic Management, has been inextricably bound with Structure-Conduct-Performance Paradigm. This fact is of particular importance when considering the sources of differences between the positioning and resource-based views in the modern Strategic Management which is due to the origins of positioning view in the Industrial Organization Economics, while the resource-based view in Business Policy.

Value of the paper: The main value of the paper is to familiarize with the issue of SCP Paradigm and to recognize its significance for the development of the various assumptions of IO Economics and Strategic Management.

Keywords: Industrial Organization Economics, Structure-Conduct-Performance Paradigm, Strategic Management

Paper type: General review 
THE ROLE OF THE STRUCTURE-CONDUCTPERFORMANCE

Zbigniew Matyjas

\section{Introduction}

One of the central issues in both strategic management (and previously its precursor- Business Policy), as well as Industrial Organization Economics, is to seek answers to the question about the sources of economic success. And as in the first case one could say that the only responsible entity for the good result is a firm, it is not so obvious in the case of IO Economics. In the latter case both theorists and researchers think in terms of a much broader context, taking into account the mechanisms leading to success. And at the same time in both scientific branches the final result of success is analogous- to achieve superior economic result, to simplify higher profitability.

It should be noted that the mechanism of seeking answers in the IO Economics was very strongly fixed in the research from the very beginning stage of this theory. The situation of the early development of strategic management (then identified as Business Policy) is best conveyed by D. Hambrick and M.-J. Chen (2008), who in their study on the methodology for the development of strategic management quote the opinion of D. Guth- one of the main authors of Business Policy: "Business Policy has all the characteristics of a religion. A lot of belief, no empirical knowledge" (Hambrick and Chen, 2008, p 38). This clearly indicates a lack of knowledge and awareness of the paucity of empirical methods in the traditional approach to strategy, leading to the need to adopt a scientific rigor of other scientific disciplines. One of them was the Industrial Organization Economics, which largely supported the development of strategic management, providing methodological foundations, which are the most important ones of the entire subsequent positioning approach (or school) within today's Strategic Management.

IO Organization as a scientific discipline in the first period of its development was based solely on the so called SCP Paradigm (Structure-ConductPerformance), also known as the Bain/Mason concept (Bain, 1956; Mason, 1939), whose central theme was the relationship between actions and performance of the firms, and the structure of the industry they operate. The subsequent stage of the development of SCP Paradigm was subject to change, which crucially influenced not only the development of Industrial Organization Economics, but also Strategic Management. Its importance is particularly essential in sectors characterized by imperfect competitive conditions, which are in opposition to the classical situation of "perfect competition", well and widely recognized within the field of microeconomics. In fact, the economic conditions in most of the industries are similar to the conditions of imperfect competition, hence the large applicability of SCP Paradigm for many sectors and companies.

In today's Strategic Management literature SCP paradigm does not draw a special attention, particularly in monographs and textbooks in the Polish literature. It is sometimes barely mentioned in some monographs within the field 
of strategic management usually in a very fragmentary and clearly insufficient way. Hence, the purpose of this paper is to introduce the basic assumptions of the Structure-Conduct-Performance paradigm, its origin and subsequent significant changes, methods of empirical confirmation of its existence and its importance for the development of Industrial Organization Economics and Strategic Management.

\section{Structure-Conduct-Performance Paradigm - the historical development of the idea}

The logic of the SCP paradigm is presented in Figure 1, its basic premise is the belief that the performance of the companies within every industry is affected by their conduct (generally understood as management), which in turn are conditioned to a large extent by the structure of the sector in which companies operate. That basic premise of the paradigm led, according to M. Porter (1981), to the conclusion that in reality the level of firm profitability in the industry is mainly influenced by the nature of industrial factors shaping its structure. The influence of factors

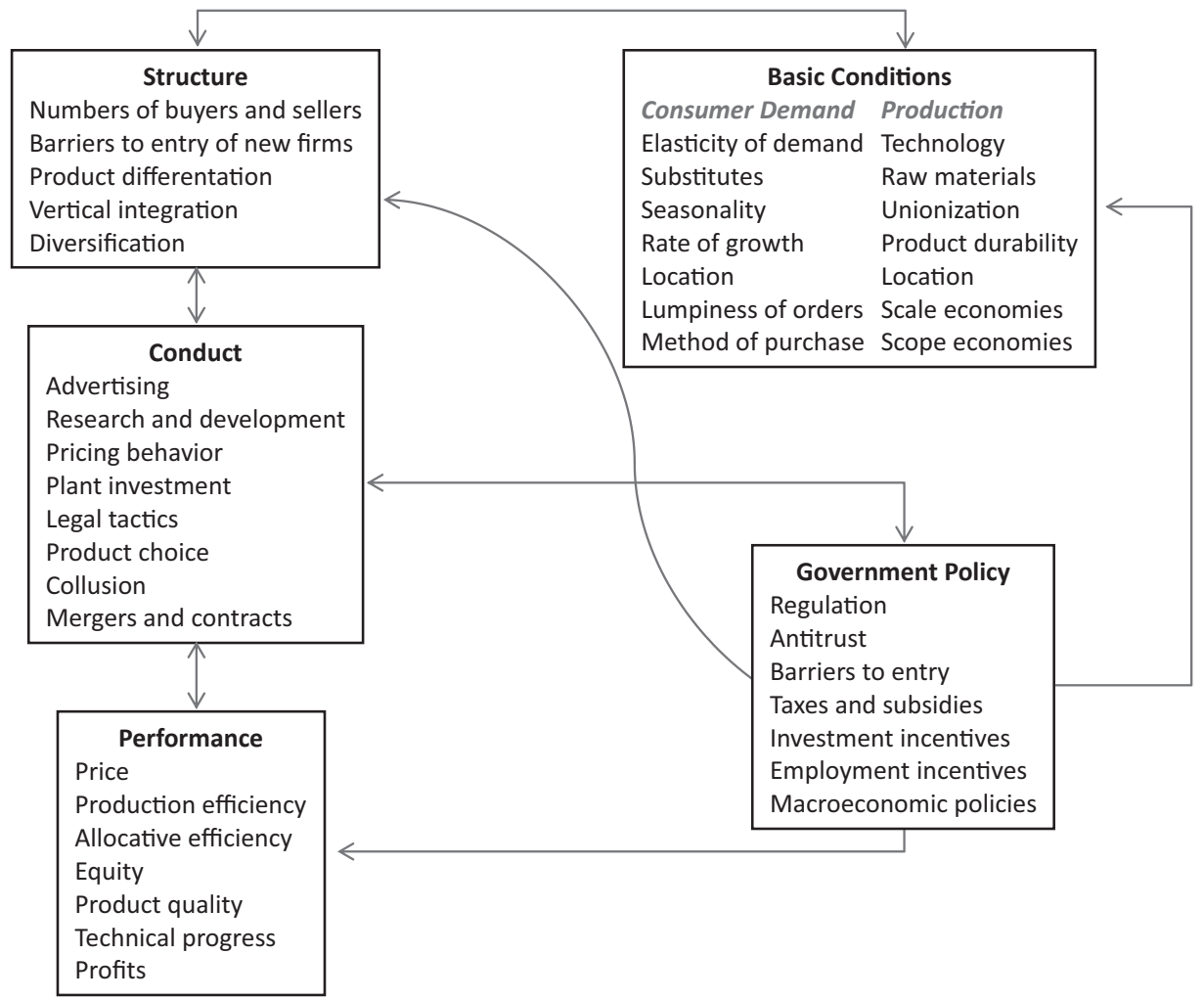

THE ROLE OF THE STRUCTURE-CONDUCTPERFORMANCE

Zbigniew Matyjas
Figure 1. Structure-ConductPerformance Paradigm 
THE ROLE OF THE STRUCTURE-CONDUCTPERFORMANCE

Zbigniew Matyjas related to the strategies of companies was regarded as insignificant, due to its high dependence by the industry structure. This in turn led to the conclusion that in fact the only important factors are industrial ones, so if the company intends to improve its profitability, it should choose the proper industry which is characterized by a higher level of attractiveness. The IO Economics approach differed significantly in their essence from the basic presuppositions of Strategic Management, where a strong emphasis was put on the importance of firms' strategy, which could in almost every possible way shape their results through the processes of crafting and implementing of their strategies.

Origins of the SCP paradigm can be traced in the work of a Harvard economist, E. Mason, who in the 1930's dealt mainly with issues of mechanisms of pricing and production policies of large U.S. corporations (Mason, 1939). The basis of his idea was the belief that an important determinant of these policies was companies' market share. There were two possible ways of proving this concept: the theoretical one with the use of monopolistic and oligopolistic models of activities of firms in the industry, and empirical one, looking for the relationships between the observed prices and other variables reflecting differences in the structure of the market. E. Mason decided to lead to the empirical observation of these compounds, which in his view would be a strong confirmation of the importance of the industrial structure on the decisions undertaken by the companies in terms of pricing and production policies. Even then, he assumed that the market structure is a multidimensional concept, it can be measured by, among others, the following variables: characteristics of the product, cost and characteristics of manufacturing, the number and market shares of buyers and suppliers in this industry. Additional factors affected the structure of the industry are its life cycle and distribution channels. Thus, the first key assumptions of the SCP paradigm were presented by E. Mason back in the late 1930's, but there was still the lack of empirical confirmation of the validity of this concept.

The next step in the development of this paradigm was done by J. Bain. However, in contrast to his predecessor, his work in this area was mainly empirical one. Based on a series of data from the industry, he clarified the individual components of the paradigm, which, in his opinion, consists of the following factors (Bain, 1956):

- Structure- relating to the structure of the industry. It is generally assumed that it consists of variables such as the number of buyers and suppliers, barriers to entry for new firms, product differentiation, the extent of vertical integration, and diversification. These variables can be further subdivided into internal structural variables ( determined by the nature of the products and technology available in the sector) and dependent structural variables (determined by companies or governments); 
- Conduct- factors relating to the activities of a strategic nature undertaken by companies in the industry. Currently the can be viewed as firms' strategies, which may consist of: advertising, expenditure on research and development, pricing behavior, plant investment, legal tactics, product mix, tacit collusions, mergers, and contracts;

- Performance- generally understood from the economical, or even the financial perspective of the company in an industry. They can take the form of variables such as price, production efficiency, allocative efficiency, equity, product quality, technical progress, and ultimately the most popular profits. Although in the model theoretically occur numbers of different potential possibilities, empirical studies usually take one of two measures: profitability or profit margin.

Apart from the above factors there are two additional areas that affect the conditions of the SCP Paradigm. The first is government policy that can significantly affect the conditions of the industry, in particular through the ability to actively shape the barriers to entry into it. Typically, the following components are considered as governmental policies: regulation, the antitrust acts, entry barriers, taxes and subsidies, investment incentives, incentives to increase employment, and macroeconomic policies. The second area is the assumption underlying the field of consumer demand and the actions of suppliers, both of these groups can have a significant impact on the conditions of the industry. The most important within the field of consumer demand are: elasticity of demand, substitutes, seasonality, growth rate, location, lumpiness of orders, and method of purchase. Within the field of suppliers there are variables as: technology, raw materials, unionization, product durability, location, economies of scale, and economies of scope. All of these variables influencing at the level of government policy, consumer demand and suppliers activities can also change the conditions of competitiveness within the industry, which in turn allows them to influence the performance of companies.

The logic of the SCP Paradigm indicates the possibility of the occurrence of one of a number of potentially possible situations in terms of the relationship between the three basic components. The original scheme of understanding the SCP Model is presented in Figure 2. According to it, there was a basic assumption that the structure of the sector determines the conduct of the company, which in turn affects its performance.

Industry Structure Conduct Performance

SCP Paradigm met with criticism, which led to consider that the level of the firm (namely: conduct) is much more important for the whole SCP Paradigm. It was also consistent with many observations derived directly from business 
THE ROLE OF THE STRUCTURE-CONDUCTPERFORMANCE

Zbigniew Matyjas

Figure 3.

Modern version of SCP paradigm

Source: based on:

Lee (2007: 5). practice where companies were able to change the structure of the industry as a result of their strategies. This was consistent with the observation of the heterogeneity of strategies of companies in the industry, which broke one of the main patterns of thinking in SCP Paradigm. According to classical model of Industrial Organization Economics the only prerequisite for differentiating companies within the industry was their scale of operation. Hence, they were all seen as strictly homogeneous (standardized) from the point of view of their strategies. Meanwhile, since the 1970s there has come up a new idea, as one of the first developed both within IO Economics as well as in Strategic Management, which is called the strategic groups concept (Matyjas, 2011). One can quite clearly say that it has brought a fundamental breakthrough in the process of merging of these two different disciplines. On the one hand it allowed to introduce to the key concepts of SCP Paradigm within Industrial Organization Economics the idea of heterogeneity of strategies of companies within the industry, on the other hand, it was one of the first concepts, which aroused strong interest for the research within the Strategic Management field.

The theory of strategic groups had a strong impact on the change of StructureConduct-Performance Paradigm, primarily due to the overthrow of the initial assumption that companies in the industry don't differ in any other strategically important parameter than the scale of their operations. This caused repercussions in the form of changes of the understanding of the SCP model (Figure 3).

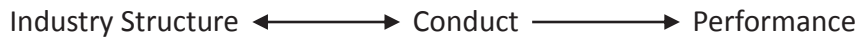

According to the new version of the SCP Paradigm both structure of the industry and firms' strategies interact. This means that not only the structure of the sector determines the choice of company strategy (although this relationship still exists), but also the strategies undertaken by companies in the industry can affect its structure.

\section{Mechanisms of empirical confirmation of Structure-Conduct-Performance Paradigm}

It should be noted that, despite later changes, the SCP Paradigm itself played a significant role in understanding the basic mechanisms of competition, which has been lately used by strategic management. It played at least the same role for Industrial Organization Economics for many years. IO Economics was definitely perceived as much more strictly scientific branch of knowledge than Business Policy (characterized by a relatively low level use of rigorous research and the lack of generalization, therefore not treated as strictly academic field of knowledge). Until 1970s there was conducted the hundreds of studies confirming the validity of the original assumptions of the SCP paradigm (Ghemawat, 2002). 
The traditional Industrial Organization Economics mainstream mainly deal with rigorous industrial research (individual) and cross-industrial comparisons.

The mechanism of empirical confirmation of the validity of the basic assumptions of the SCP paradigm ran in two ways, in addition to empirical results, it was also necessary to develop the basic variables to facilitate subsequent empirical research. Variables confirming the validity of the SCP paradigm are usually divided into four groups (Lee, 2007):

a) Theoretical Variables- they enable you to measure the relationship between market structure, strategy and results. The mechanism of removal is usually inferred from the Cournot duopoly model, because of the de facto occurring causal ambiguity primary way to measure is the assumption that an increase in industry concentration affected positively the growth of profitability of firms;

b) Measuring Performance Variables- it is one of the key issues in the literature. Commonly used measures are the profitability ratios, like ROA or ROE (Venkatraman and Ramanujam, 1986), which are easy to interpret. In addition to that are such measures as (Lee, 2007):

- Lerner index which measures the strength of the company's market, it is assumed that if he adopts a value higher than zero, it means that the company has a market value. Its disadvantage is the difficulty in its practical application due to the need to obtain information on the amount of marginal costs.

$$
\text { Lerner's Index }=\frac{\text { price }- \text { marginal cost }}{\text { price }}
$$

- Tobin's q ratio which measures the ratio of firms stock market value to replacement cost of capital, where $M_{c}$ is the market value of ordinary shares, value of preference shares is $M_{p}, M_{d}$ outstanding loan capital, while $A_{r}$ replacement cost of total assets. When $q>$ 1 , the company has intangible assets or advantages which are not included in the valuation of assets, as market power.

$$
q=\frac{M_{c}+M_{p}+M_{d}}{A_{r}}
$$

c) Measuring Concentration Variables show, what the realities of competition in the industry are. Among several possible the following indicators deserve attention:

- The degree of concentration in the industry ratio which measures the total share of $\mathrm{m}$ firms with the largest share in the industry, its
THE ROLE OF THE STRUCTURE-CONDUCTPERFORMANCE

Zbigniew Matyjas 
THE ROLE OF THE

STRUCTURE-CONDUCTPERFORMANCE

Zbigniew Matyjas disadvantage is the lack of proper distribution of market shares among all companies in the sector.

$$
C R_{m}=\sum_{i=1}^{m} s_{i}
$$

- Herfindahl-Hirschman Index (Hirschman, 1964), which is devoid of the disadvantages of the previous ratio. It measures the concentration of the total (significant) players and moves in a range of 0 (absolutely perfect competition) to 10,000 (monopoly).

$$
H H I=\sum_{i=1}^{n} s_{i}^{2}
$$

d) Other independent variables- the fourth group of variables can include many more variables that measure, for example, the scale of barriers to entry into the industry (one measure here is a measure of the minimum efficient scale of production).

Apart from the issue of developing a list of variables needed to conduct a research, an important feat confirming the importance of the SCP Paradigm was to conduct empirical research. The first tests have already appeared in the $1950 \mathrm{~s}$, one of their key problems was to develop and estimate a list of barriers to entry into industry (Bain, 1956). An important issue carried out in this research was to confirm the relationship between the profitability of the industry, and the degree of its concentration. There were carried out hundreds of studies on that subject that finally confirmed that assumption. Then the research context has gradually moved towards the observation of the importance and impact of industrial variables on the profitability of firms in comparison to the influence of the firm-level (strategic) factors. If the initial assumptions of the SCP Paradigm were right, then one would expect a much greater degree of impact of the industrial variables in comparison to firm-level variables. Such research have been carrying out to date (Matyjas, 2013; Matyjas, 2013b).

To summarize the scope of work and the importance of the SCP Paradigm it should be clearly stated that it has had far-reaching implications regarding the mechanisms of understanding the economical logic of industries. Although some assumptions of the model were not confirmed, and some have been updated, nevertheless it should be noted that the model itself has had a across-the-board impact on several disciplines, among which a beneficiary was, understandably, IO Economics, and the second largest- Strategic Management. Under SCP Paradigm, as well as the entire IO Economics, many studies were conducted in 
further development of strategic management. Noteworthy among others are transaction cost theory (Williamson, 1989), vertical integration (Perry, 1989), or the cross-industrial studies on the structure and performance of these industries (Schmalensee, 1989). The SCP Paradigm was also benefited by the development of competitive dynamics (Smith et.al., 2001), assuming that the strategic actions undertaken by some companies could lead to retaliatory actions taken by other companies, which in turn can lead to hyper-competition (D' Aveni, 1994), which led to the break of the initial stereotypes of IO Economics.

\section{Summary}

The Structure-Conduct-Performance Paradigm has played a vital role in the Industrial Organization Economics (especially in the first period of its development), which in turn was associated with its essential role in the development of Strategic Management. The main importance was its strong support of research under the SCP Paradigm in scientific methodology and correct inference. Assumptions of the IO Economics based particularly on the SCP Paradigm allowed increasing the knowledge of strategists on the determinants that govern the competitive game in any industry. However, this direction had many limitations for its direct application in its original form for the purpose of crafting strategy. They included, among others, (Porter, 1981): completely different perceptions of barriers to entry into the sector from the perspective of managers (for IO Economics barriers to entry were perceived as negative effects while for Strategic Management it is the opposite), basing on a different level of analysis (for strategic management it is the level of the company, for the IO Economics- industrial level) and static analysis of industrial perspective along with her determined nature (in contrast to Strategic Management the discipline of Industrial Organization Economics assumed that this structure is fixed).

IO Economics, in contrast to the completely absorbed by Strategic Management Business Policy, is today an independent economic discipline (Besanko et. al., 2004), which supports the process of educating future strategists in many important (from a strategic point of view) aspects such as: the scope and boundaries of companies, types of economics in the company (scale, scope and time), ways to diversify the company's activities, analysis, and price differences between rival firms, market conditions in the business activity (monopolistic, oligopolistic and perfect competition), the structure of the industry and markets, and many other detailed aspects.

The development of both Industrial Organization Economics, as well as Strategic Management, has been inextricably bound for many years with the Structure-Conduct-Performance Paradigm. This fact is of particular importance when considering the sources of differences between the positioning and resourcebased views in the modern Strategic Management. This is substantially due to the
THE ROLE OF THE STRUCTURE-CONDUCTPERFORMANCE

Zbigniew Matyjas 
THE ROLE OF THE STRUCTURE-CONDUCTPERFORMANCE

Zbigniew Matyjas origins of positioning view in the Industrial Organization Economics, while the resource-based view in Business Policy (Matyjas, 2013c). Hence, recognizing the importance of the SCP Paradigm is important for both the understanding of the functioning of the various assumptions of IO Economics and Strategic Management, as well, as the relationship between these two disciplines.

\section{References}

Bain, J.S. (1956), Barriers to new competition, Harvard University Press, Cambridge.

Besanko, D., Dranove, D., Shanley, M., Schaefer, S. (2004), Economics of Strategy, Wiley, Hoboken, NJ.

Carlton, D.W., Perloff, J.M. (2005), Modern Industrial Organization, Pearson, Addison Wesley.

D’Aveni, R.A. (1994), Hyper Competition: Managing the Dynamics of Strategic Maneuvering, Free Press, New York.

Ghemawat, P. (2002), "Competition and Business Strategy in Historical Perspective", Business History Review, Vol. 76, Spring, pp. 37-74.

Hambrick, D.C., Chen, M.-J. (2008), "New academic field as admittance-seeking social movements: the case of strategic management", Academy of Management Review, Vol. 33, pp. 32-54.

Hirschman, A.O. (1964), “The Paternity of an Index", American Economic Review, September, pp. 761-762.

Lee, C. (2007), "SCP, NEIO and Beyond", Working Paper Series Vol. 2007-05, Nottingham University Business School, University of Nottingham Malaysia Campus, March.

Mason, E.S. (1939), "Price and production policies of large scale enterprises", American Economic Review, Vol. 29, pp. 61-74.

Matyjas, Z. (2011), „Koncepcja grup strategicznych - w stronę dynamicznych modeli konkurowania (przegląd badań światowych)", in: Urbaniak, M. (Ed.), Aktualne trendy $w$ naukach o zarzadzaniu, finansach i rachunkowości, Vol. 2, Folia Oeconomica 258, Wyd. Uniwersytetu Łódzkiego, Łódź, pp. 77-93.

Matyjas, Z. (2013a), "Firm and Industry Effects on Company Performance: Evidence From Polish Listed Companies", $9^{\text {th }}$ EBES Conference-Rome Proceedings, Italy, January 11-13, pp. 2356-2366.

Matyjas, Z. (2013b), "Industry and Firm Influences on Performance: Evidence From Polish Public Firms", $4^{\text {th }}$ Annual International Business Conference Saint Leo University, Tampa, USA, February 13-15, pp. 133-144.

Matyjas, Z. (2013c), Wzorce konkurowania przedsiębiorstw w sektorach - podejście dynamiczne, Wydawnictwo Uniwersytetu Lódzkiego, Łódź.

Perry, M.K. (1989), "Vertical Integration: Determinants and Effects", in: Schmalensee R., Willig R.D. (Eds.), Handbook of Industrial Organization. Vol. 1, Elsevier North Holland, Amsterdam, pp. 183-258.

Porter, M.E. (1981), “The Contributions of Industrial Organization to Strategic Management", Academy of Management Review, Vol. 6, pp. 609-620. 
Schmalensee R., Willig R.D. (Eds.), Handbook of Industrial Organization. Vol. 2, Elsevier North Holland, Amsterdam, pp. 951-1009.

Smith, K.G., Ferrier, W.J., Ndofor, H. (2001), “Competitive Dynamics Research: Critique and Future Directions", in: Hitt, M.A., Freeman, R.E., Harrison, J.S. (Eds.), Handbook of Strategic Management, Blackwell, London, pp. 315-361.

Venkatraman, N., Ramanujam, V. (1986), "Measurement of Business Performance in Strategy Research: A Comparison of Approaches", Academy of Management Review, Vol. 11, pp. 801-814.

Williamson, O.E. (1979), "Transaction-Cost Economics: The Governance of Contractual Relations", The Journal of Law and Economics, October, pp. 233-261. 